\title{
Fuel cell based micro-combined heat and power under different policy frameworks - An economic analysis
}

Hansen, Lise-Lotte Pade; Schröder, Sascha Thorsten

Published in:

Energy Conversion and Management

Link to article, DOI:

10.1016/j.enconman.2012.10.012

Publication date:

2013

Link back to DTU Orbit

Citation $(A P A)$ :

Hansen, L-L. P., \& Schröder, S. T. (2013). Fuel cell based micro-combined heat and power under different policy frameworks - An economic analysis. Energy Conversion and Management, 66, 295-303.

https://doi.org/10.1016/j.enconman.2012.10.012

\section{General rights}

Copyright and moral rights for the publications made accessible in the public portal are retained by the authors and/or other copyright owners and it is a condition of accessing publications that users recognise and abide by the legal requirements associated with these rights.

- Users may download and print one copy of any publication from the public portal for the purpose of private study or research.

- You may not further distribute the material or use it for any profit-making activity or commercial gain

- You may freely distribute the URL identifying the publication in the public portal 


\title{
Fuel Cell-based micro-combined heat and power under different policy frameworks - an economic analysis
}

\author{
Post-print version of the article appeared in \\ Energy Conversion and Management, \\ Volume 66, February 2013, Pages 295-303 \\ Lise Lotte Pade ${ }^{a} *$ and Sascha Thorsten Schröder ${ }^{a}$ \\ ${ }^{a}$ Technical University of Denmark,Department of Manegement Engineering, Energy \\ Systems Analysis, DTU Risø Campus, P.O. Box 49, DK-4000 Roskilde, Denmark \\ *Corresponding author: llph@dtu.dk; phone: +45 4677 5194, fax: +45 46775199
}

\begin{abstract}
The residential fuel cell technology faces a list of challenges, of which some are linked to the technology through the need of cost decreases and reliability improvements. Others are linked to the political stage, where the necessary support schemes have to be in place in combination with clear political objectives on the design of the future energy system.

This article takes the point of departure in the existing support schemes, most common ownership structures, energy prices, electricity demand and heating demand in Denmark, France and Portugal. For the three countries, we analyse different constellations of operational strategies, ownership structures and promotion schemes and assess the necessary support levels for residential fuel cells under these constellations.

We find that the necessary support levels are not excessively high compared to the initial support levels for e.g. photovoltaic systems in Germany. Especially net metering in Denmark and price premiums for fuel cells functioning as a virtual power plant in France and Portugal seems promising. The annual number of operation hours depends strongly on the operational scheme. For thermal-led units, coldstart and modulation capacity plays a certain role, whereas the fuel cell generates virtually permanently if it is part of a virtual power plant.
\end{abstract}

Keywords: FC, support mechanisms, microCHP, stationary fuel cells, operational strategies

\section{Introduction}

It is widely recognised that fuel cell based micro-Combined Heat and Power systems may contribute substantially to altering the energy system at the residential level [1]. Traditionally, the customers rely on centralised electricity producers delivering electricity through the grid. Fuel cell based micro-combined heat and power (FCbased microCHP) will be able to contribute to an innovative system where the customer produces his own heat and partly his own electricity. Depending on who 
owns the fuel cell and who is in charge of operating it, some units, if operated by e.g. an energy company, can interact together, working as a virtual power plant.

The stationary fuel cell technology is still in a rather early stage of development and faces a range of challenges. One of the main challenges of the fuel cell technology is the efficiency while others are the cost level and the reliability of the fuel cell.

It is questionable if investors such as households or energy companies are willing to engage in the fuel cell technology before these conditions have improved. Clear political objectives will contribute to assuring that the investors face long term planning perspectives and regulation in the field has to be clear and contribute to creating the market opportunities e.g. through investments in R\&D. As the costs of investing in fuel cells are still relatively high, private investors need financial incentives in order to invest in a fuel cell. These incentives could be provided either through operating support such as feed-in tariffs or through start-up financing such as investment support [2][3].

Existing literature covers mainly aspects like operational strategies [4], [5], [6] from which major development focuses can be derived. [7] finds that the development of SOFC cells should focus on modulating in order to be able to provide balancing services to a system with a high share of fluctuating renewable generation. For this reason, the number of operation hours and thus, the overall lifetimes becomes less important. A contrary view is found in [8], where increased lifetime is seen as a major path towards accelerated market entry. It has been suggested that a variable heat-topower ratio would be desirable for covering electricity and heat demand in a single house [9]. When comparing microCHP SOFC systems to alternative technologies, they are a rather expensive solution [10]. Possible future price ranges for SOFC systems have been derived by experience curves [11] and the very recent study [12]. A major study combining different house types and possible microCHP technologies for the UK stresses the interaction with policy measures to improve energy efficiency and concludes that support should focus on units with a low heat to power ratio [13]. An early study in the field of major economic determinants for microCHP profitability finds that dwellings with larger energy demands can benefit more. This could also apply to households with electric vehicles in the future [14]. A number of studies analyse the technical, economic and environmental aspects of a list of technologies for residential cogeneration [15]-[19]. Furthermore, investment cost, lifetime and power import/export prices from the dwelling are major determinants for the results [20]. It is concluded that a considerable unsubsidised deployment before 2025 constitutes a major challenge.

Stationary fuel cells as a part of a distributed generation system are regarded as a potential to improve the national security of supply as well as increase the national competitiveness. If microCHP systems are to contribute to energy policy goals, the next link in the chain towards commercialisation is to provide suggestions for support scheme design. This is the scope of this article.

In this article based on [21], we address the challenges of the fuel cells regarding the necessary support schemes and ownership structure. We have taken the point of departure in the existing support schemes, most common ownership structures, energy prices, electricity as well as heating demands in Denmark, France and Portugal. Considering a stakeholder analysis [22] and the theory of the most appropriate support 
scheme based on the stage of the technology, we combine different ownership structures, support schemes and operational strategies in order to determine the necessary support level. After describing the general model, we turn towards country cases for the most relevant combinations of operating schemes and support scheme designs. Sensitivity analyses on core economic aspects follows before drawing the main conclusions. Our findings show that net metering is a promising support mechanism in Denmark for households with a high electricity consumption. This is due to a rather high end consumer price in Denmark. In France and Portugal the virtual power plant on the day ahead market appeared to be the most promising support scheme. In France this result is driven by the rather low natural gas price giving the fuel cell running many hours an advantage. In Portugal the result is given by a high electricity spot price improving the conditions for the electricity seller.

\section{Scenario definitions}

We perform a range of analyses with the purpose of determining which support schemes are the most appropriate to apply. We identify a range of scenarios depending on ownership arrangement, control strategy and support scheme. Furthermore, a cash-flow model yields an indication of the required level of investment or price support in order to make the technology economically viable and possibly an argument for political justifiability. The aim of the model is thus to assess which support levels have to be granted under different promotion schemes and ownership arrangements.

First of all we distinguish between two ownership arrangements, inspired by [23]:

1. Consumer-control: The household buys, installs and operates the fuel cell

2. Company control: The fuel cell is bought and run by a company e.g. an electricity or gas provider, but installed in the individual households.

Furthermore, we distinguish between three control strategies: ${ }^{1}$

1. Thermal control strategy

The fuel cell is running with the purpose of fulfilling as large a share as possible of the heat demand of the household. The electricity produced is either exported directly to the grid or consumed by the household. Whenever the fuel cell is not able to fulfil the heating need of the household (e.g. during the summer the fuel cell is turned off) a gas furnace provides the heat. The household is equipped with a heat storage of $200 \mathrm{l}$.

\section{Thermal control strategy considering peak periods}

The fuel cell is running with the purpose of fulfilling as large a share as possible of the heat demand of the household. However, when there is the opportunity to shift the operating hours of the fuel cell, the control strategy assures that the fuel cell produces during peak periods. That way, the household is able to reduce electricity demand or increase electricity export during the peak periods. The heat storage of $200 \mathrm{l}$ can be used actively to shift the usage of the fuel cell to periods with higher end user electricity prices.

\footnotetext{
${ }^{1}$ The control strategies are in correspondence with the control strategies applied in [25]
} 
3. Virtual power plant (VPP):

When the fuel cell functions as a VPP, it runs independent of the heating demand profile of the household. Instead, the control strategy only takes the electricity prices into account and will, independently of the heating need of the household, determine whether to run the fuel cell or not. In order to assure this independency, we have assumed that excess heat can be blown off costlessly such that the heat storage does not put any boundaries on the use of the fuel cell. This operation mode corresponds to summer periods with high electricity prices, but insufficient heat demand. The VPP strategy can either be based on the day-ahead market for electricity or act on the regulating power market (see [24] and references therein for further details and implementation examples of regulating power markets in Europe). In the latter case, the control strategy is designed such that the fuel cell runs 50 percent load all the time in order to be able to work both as upward regulation as well as downward regulation. If the fuel cell was operating according to the spot price when there was no need for regulating power, we would not be certain that the fuel cell could be a player on the regulating power market.

We have decided to base our analyses on four different support schemes: net metering, feed-in-tariff direct export, feed-in-tariff with self-consumption and price premium:

1. In the net metering case, the electricity meter is designed such that the meter is able to run backwards whenever the electricity production from the fuel cell is higher than the electricity consumption in the household. Basically this means that the household receives the difference between the end consumer price and the market price of electricity as a variable (due to the variation in the market price) price premium. The regarded time period for netting is one year. Net metering is only used for the thermal control scenarios.

2. The second support scheme is feed-in-tariff (FIT). In practice, this means that the household is equipped with two electricity meters - one for electricity import (consumption) and one for electricity export (production). For the electricity export the household is paid a fixed feed-in-tariff per $\mathrm{kWh}$. The feed in tariff is only used for the thermal control scenarios.

3. The third support schemes are feed-in-tariff with self-consumption (FITS). In the case with self-consumption, the household consumes electricity (if there is an electricity consumption at the specific moment) whenever the fuel cell produces. If the electricity production from the fuel cell exceeds the consumption, the household exports the exceeding electricity to the grid. If, on the other hand, the electricity consumption exceeds the production, the household imports electricity from the grid at the regular final consumer price. In the peak period control strategies the household faces two different end consumer prices: peak and off peak. For the electricity exported to the grid, the household is paid a fixed feed-in-tariff per $\mathrm{kWh}$. In practice this means that the price the household faces for the self-consumed electricity 
corresponds to the feed-in-tariff. The feed in tariff with self-consumption is only used for the thermal control scenarios.

4. The last support scheme considered is a price premium where all electricity is sold to the grid. The seller of the electricity, e.g. the electricity or gas provider, receives a fixed premium on top of the market price of electricity. The price premium is only considered for the virtual power plant scenarios.

The above mentioned ownership structures, control strategies and support schemes leaves us with eight possible combinations illustrated in this combination-tree (Figure $1)$.

Figure 1 Combinations of ownership structure, control strategies and support schemes

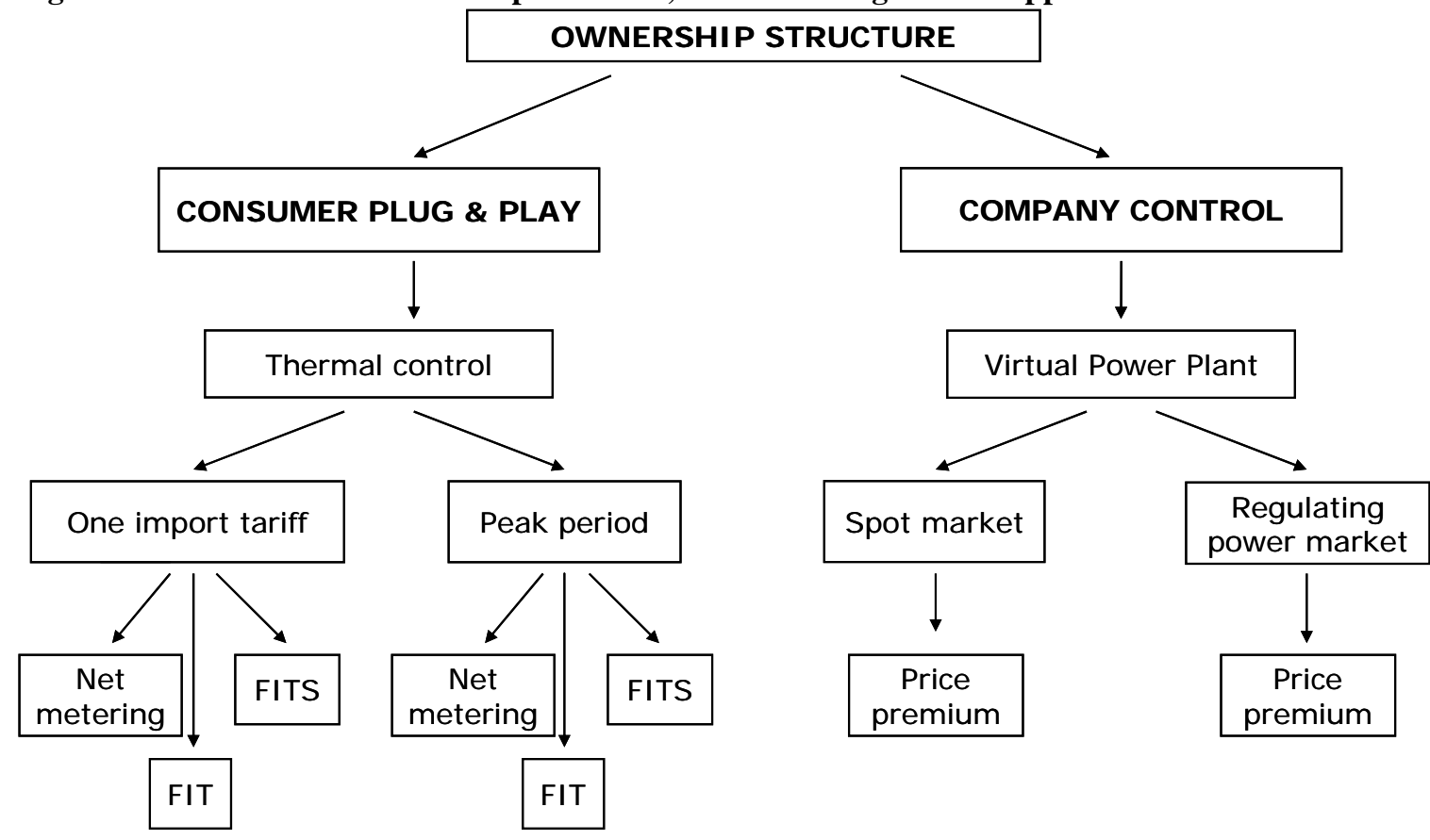

The stakeholder analysis [22] shows that for Denmark, both ownership arrangements are relevant. This is motivated by the assumption that some users are "homo oecologicus activus", i.e. consumers who consider themselves as active promoters of environmental protection and others are "homo oeconomicus", i.e. users who, given the information at hand, are aiming to maximize their own economic benefits and minimizing resources [22]. In France, the consumer control seems to be the most realistic from a sociological point of view because installations have traditionally been owned by households. The indication is therefore a result of path dependency. In general, the focus group in Portugal is the one among the three countries being most sceptic towards fuel cell based microCHP. Therefore, the ownership structure with the least transaction and maintenance costs for the households and the least risk for the service providers is considered as the most appropriate one. Thus, in Portugal the company control is the most probable. 
In addition to the recommended combinations of ownership arrangements and support schemes, we have chosen to conduct complementary national focus analyses. For Denmark, we also analyse a feed in tariff since there is a tradition in Denmark for using feed in tariffs in the rather early stage of a new technology, e.g. wind power. Furthermore, as net metering is already applied for other small-scale technologies such as photovoltaic in Denmark, we also consider this support tool here. For France, we analyse the situation where the fuel cell is owned and operated by a large company in order to capture the possibility of residential fuel cells to work as a virtual power plant. Finally, for Portugal we have chosen to analyse two privately owned scenarios: the thermal control - feed in tariff with self-consumption and peak period - net metering. These analyses are made in order to determine the extent to which it is possible to maintain an incentive for private households to invest in a residential fuel cell. The scenarios analysed for the three countries are summarised in Table 1. All cases have in common that a microCHP unit with a low capacity complements the existing gas furnace technology. The reason for this choice is that a unit with a small capacity achieves a higher number of full-load operation hours, which is more promising from an economic perspective. Furthermore, the gas furnace remains the major heat supply of the dwelling which can render microCHP units more attractive also for risk-averse home owners. With regard to the existing gas furnace, we assume that when renewing it, its capacity can be reduced by the thermal capacity of the microCHP unit.

Table 1 Choice of control strategy, support schemes for Denmark, France and Portugal

\begin{tabular}{|c|c|c|c|c|c|c|}
\hline Country & Control strategy & Support scheme & $\begin{array}{c}\text { Capacity } \\
\text { (kW) }\end{array}$ & Housetype & Fuel cell & $\begin{array}{c}\text { Efficiency, } \\
\text { electricall } \\
\text { overall }\end{array}$ \\
\hline \multirow[t]{2}{*}{ Denmark } & Thermal control & Net metering/FIT & 1 & Old/new & LEE $^{a}$-SOFC & $40 / 90$ \\
\hline & $\begin{array}{ll}\text { VPP } & \text { spot } \\
\text { market/ } & \\
\text { regulating } & \text { power } \\
\text { market } & \end{array}$ & Price premium & 2 & Old/new & $H_{E E}{ }^{b}-S O F C$ & $60 / 80$ \\
\hline \multirow[t]{3}{*}{ France } & Thermal control & $\begin{array}{l}\text { Net metering } \\
\text { /FIT/FITS }\end{array}$ & 1 & Old/new & LEE-SOFC & $40 / 90$ \\
\hline & $\begin{array}{l}\text { Thermal control/ } \\
\text { peak periods }\end{array}$ & FIT/FITS & 1 & Old/new & LEE-SOFC & $40 / 90$ \\
\hline & $\begin{array}{l}\text { VPP } \quad-\quad \text { spot } \\
\text { market }\end{array}$ & Price premium & 2 & Old/new & HEE-SOFC & $60 / 80$ \\
\hline \multirow[t]{3}{*}{ Portugal } & Thermal control & FITS & 1 & Old/new & LEE-SOFC & $40 / 90$ \\
\hline & $\begin{array}{l}\text { Thermal control - } \\
\text { peak periods }\end{array}$ & Net metering & 1 & Old/new & LEE-SOFC & $40 / 90$ \\
\hline & $\begin{array}{l}\text { VPP }- \text { spot } \\
\text { market }\end{array}$ & Price premium & 2 & Old/new & HEE-SOFC & $60 / 80$ \\
\hline
\end{tabular}

'LEE abriviates 'low electrical efficiency'

b HEE abriviates 'high electrical efficiency'

\section{Model description}

The cash-flow model has the primary target to assess the adequate support levels that have to be granted under different promotion schemes and ownership arrangements. 
The cash-flow model presents the time series of monetary flows of the investment, covering both income and expenses and presents the sum of the net present values of the investment. The time horizon of the investment and hence the model is limited to 10 years. Table 2 provides an example of the cash-flow for net metering in the Danish case.

Table 2 Cash-flow model - support level example, net metering, (DK)

\begin{tabular}{|c|c|c|c|c|c|c|c|c|c|c|}
\hline & Year 1 & Year 2 & Year 3 & Year 4 & Year 5 & Year 6 & Year 7 & Year & Year 9 & Yea \\
\hline Investment, $€ / k W$ & -5000 & & & & & & & & & \\
\hline O\&M, €/kW & -140 & -143 & -146 & -149 & -152 & -155 & -158 & -161 & -164 & -167 \\
\hline Stack exchange costs, $€ / k W$ & & & & & & -1104 & & & & \\
\hline Fuel cost, $€ / \mathrm{kW}$ & -1438 & -1467 & -1496 & -1526 & -1557 & -1588 & -1620 & -1652 & -1685 & -1719 \\
\hline Avoided power costs, $€$ & 1255 & 1280 & 1305 & 1332 & 1358 & 1385 & 1413 & 1441 & 1470 & 1500 \\
\hline Avoided heat costs, $€$ & 799 & 815 & 831 & 848 & 865 & 882 & 900 & 918 & 936 & 955 \\
\hline Avoided heat investment, $€$ & 125 & & & & & & & & & \\
\hline Opportunity costs, $€$ & -244 & -261 & -274 & -288 & -303 & -319 & -335 & -352 & -370 & -389 \\
\hline Annual sums, $€$ & -4643 & 224 & 220 & 216 & 212 & -898 & 201 & 194 & 187 & 180 \\
\hline Annual sums (€2010) & -4643 & 220 & 212 & 204 & 196 & -813 & 178 & 169 & 160 & 150 \\
\hline $\begin{array}{l}\text { Sum }(€ 2010) \\
\text { Necessary } \\
\text { support }(€ / k W)\end{array}$ & $\begin{array}{l}-3968 \\
3968\end{array}$ & & & & & & & & & \\
\hline Annual generation (kWh/kW) & 5432 & & & & & & & & & \\
\hline Total generation (kWh) & 54323 & & & & & & & & & \\
\hline
\end{tabular}

There are two kinds of inputs to the model: technical simulation results [25] and technical and economic data. The technical and economic data contains information about the capacity. In the thermal control cases, we assume the fuel cell to have a capacity of $1 \mathrm{~kW}$ as compared to a capacity of $2 \mathrm{~kW}$ in the case of virtual power plant strategy (Table 1). In the thermal control case, the purpose is to assure as many load hours as possible in order to improve the profitability of the fuel cell. In the virtual power plant case, the purpose is to achieve the highest electricity production as possible. These strategies are supported by the choice of type of fuel cell and hence other electrical and overall efficiencies. In the thermal control case, the efficiencies reflect that the primary reason to install the fuel cell is to cover the heat demand, whereas the electricity production is a secondary benefit. The electrical efficiency is 40 percent and the overall efficiency is 90 percent, i.e. the heat efficiency is 50 percent supporting the satisfaction of the heat demand in the household. These assumptions are roughly in line with the SOFC ENE-FARM units currently being deployed in [26]. In the VPP case, the primary target is to produce and sell electricity, whereas the heat production is a secondary benefit. Hence, we assume that another type of fuel cell with a higher electrical efficiency of $60 \%$ and overall efficiency of $80 \%$ is applied (Table 1). These assumptions are in line with a commercial product offered by manufacturer CFCL [27]. 
The investment costs, operation and maintenance costs and stack change expenditures are all based on a number of studies ([28]-[40]) as well as information provided by the industry. We assume the investment costs to be $5000 € / \mathrm{kW}^{2}$ We assume that the operation and maintenance costs (excluding stack exchange) constitute 140 $€ / \mathrm{kW} /$ year, being relatively optimistic. The stacks are initially expected to have a lifetime of 5 years and the stack exchange costs are assumed to be $1000 € / \mathrm{kW}$. All electricity prices as well as end consumer gas price are based on 2008 values. Analysing the virtual power plant case for Denmark, we assume that the fuel cell owner is able to achieve a 30 percent reduction in the gas price compared to the end user gas price due to economies of scale. If the household was not equipped with a fuel cell, the alternative would be a gas furnace and thus the cash flow model includes the avoided heat investments. The avoided investment costs as well as the effectivity are related to the alternative, i.e. the gas furnace.

Finally, we assume an interest rate of 5 percent and the opportunity costs are included representing the amount of money the household could have achieved by putting the money in the bank instead of investing in the fuel cell. Alternatively, under perfect capital markets, this represents the interest rate for a loan that needs to be regarded as costs.

Table 3 Background data

\begin{tabular}{llccc} 
Fuel cell & Unit & Denmark & France & Portugal \\
\hline Lifetime & $\mathrm{Y}$ & 10 & 10 & 10 \\
Capital Cost & $€ / \mathrm{kW}$ & 5000 & 5000 & 5000 \\
O\&M Cost & $€ / \mathrm{kW}$ p.a. & 140 & 140 & 140 \\
Stack change (lifetime 5 years) & $€ / \mathrm{kW}$ & 1000 & 1000 & 1000
\end{tabular}

\section{Energy prices}

\begin{tabular}{llccc}
\hline Fuel cost, end consumer gas price & $€ / \mathrm{kWh}$ & 0.11 & 0.0579 & 0.0629 \\
Electricity consumer price & $€ / \mathrm{kWh}$ & 0.3 & 0.1145 & 0.15035 \\
Electricity consumer price, day & $€ / \mathrm{kWh}$ & 0.057 & 0.1275 & 0.1489 \\
Electricity consumer price, night & $€ / \mathrm{kWh}$ & & 0.0864 & 0.08077 \\
Power Exchange Price (average) & $€ / \mathrm{kWh}$ & & 0.043 & 0.070
\end{tabular}

Interest rate etc.

$\begin{array}{lllll}\text { Real interest rate } & \text { Pct. p.a. } & 5 & 5 & 5 \\ \text { Inflation rate } & \text { Pct. p.a. } & 2 & 2 & 2\end{array}$

\section{Consumer data}

\begin{tabular}{llcrc}
\hline Electricity demand, annual & kWh & 3752 & 2937 & $2937^{\mathrm{a}}$ \\
Heat demand, annual, new house & kWh & 10541 & 8636 & $8636^{\mathrm{a}}$ \\
Heat demand, annual, old house & kWh & 19660 & 18925 & $18925^{\mathrm{a}}$ \\
\hline
\end{tabular}

${ }^{\mathrm{a}}$ Portugal is also represented by French consumption profiles.

\footnotetext{
${ }^{2}$ The assumption of proportional investment costs is assumed to be rather conservative and not necessarily in coherence with the assumption of the fuel cell producers.
} 
The technical simulations [25] are based on the same economic inputs as the cash flow model and provide on a 10 minutes-basis how the fuel cell runs for a year. The outputs from the technical simulations are:

- Gas consumption, fuel cell

- $\quad$ Gas consumption, boiler

- $\quad$ Net metering

- $\quad$ Self-consumption

- $\quad$ Electricity import

- $\quad$ Electricity export

The technical simulation results yield the following input parameters for financial calculations:

- $\quad$ the costs of running the fuel cell (fuel costs, natural gas)

- $\quad$ the avoided power costs which are positive in the cases of net metering and feed in tariff with self-consumption and zero otherwise

- $\quad$ avoided heat costs being the expenses to natural gas the household would have had otherwise

The background data for the three countries are given in Table 3. The end consumer electricity price of Denmark is rather high compared to France and Portugal, i.e. three times as high compared to France and twice as high compared to Portugal. The heat consumption is approximately the same for an old house and a new house in the three countries respectively. These levels of heat consumptions are covering room heating as well as hot water supply. The annual electricity consumption is assumed to be independent of the house type ${ }^{3}$ ([25], [41]).

\section{Results}

\subsection{Country case: Denmark}

\subsubsection{Thermal control}

The results from the analysis, summarised in Table 4, shows that the fuel cell is slightly more profitable in the case of the old house compared to a new house since the break even investment costs is highest in the old house. The electricity production of the fuel cell installed in the old house exceeds the electricity production of the fuel cell installed in the new house since the fuel cell has to run more hours in order to fulfil the (larger) heating need of the household in the old house. This is also illustrated by the number of full load hours being 4957 in the new house as compared to 5432 in the old house. The share of the heat demand covered by the fuel cell is larger in the new house, 60 pct., compared to the old house, where the fuel cell only covers 35 pct.

\footnotetext{
${ }^{3}$ Because of lack of data sources, the Portuguese consumer data are identical to those of France
} 
Table 4 Thermal control - overview - Denmark

\begin{tabular}{lll} 
& New house & Old house \\
\hline Electricity production & $4957 \mathrm{kWh} /$ year & $5432 \mathrm{kWh} /$ year \\
Electricity export (net metering) & $1220 \mathrm{kWh} /$ year & $1696 \mathrm{kWh} /$ year \\
Full load hours & 4957 & 5432 \\
Heat demand covered by FC & $60 \mathrm{pct}$. & $35 \mathrm{pct}$. \\
Break even investment costs & $2460 € / \mathrm{kW}$ & $2495 € / \mathrm{kW}$ \\
FIT & $35.8 \mathrm{c} / \mathrm{kWh}$ & $33.3 \mathrm{c} € / \mathrm{kWh}$ \\
\hline
\end{tabular}

The analyses show that a feed in tariff of $33.3 \mathrm{c} € / \mathrm{kWh}$ is necessary for the fuel cell to be profitable in an old house whereas in a new house the feed in tariff has to be 35.8 $\mathrm{c} € / \mathrm{kWh}$. This is a very high level in comparison with current support for most renewable energy technologies such as wind or biomass, but these technologies advanced considerably since their market introduction decades ago. Historically, higher feed-in tariffs of approximately $50 \mathrm{c} € / \mathrm{kWh}$ have been seen in countries like Germany and induced cost decreases in the long run.

For the Danish case, unlike the French, the net metering has the restriction that for the electricity produced exceeding the electricity consumption on a yearly basis the fuel cell owner only receives $8 \mathrm{c} € / \mathrm{kWh}$ as is the case for domestic photo voltaic [42]. If we instead assumed that we were dealing with a household with an identical heating profile but with an electricity consumption exceeding the electricity production from the fuel cell, then we have a significantly different situation. In this case, the break even investments almost corresponds to the assumed investment cost of $5000 € / \mathrm{kW}$.

\subsubsection{Virtual power plant}

In the Danish case we have analysed both the opportunity for the fuel cell to be a part of the spot market as well as the regulating power market. In order to operate on the regulating power market, we assume that the fuel cell runs at 50 percent capacity by default, i.e. $1 \mathrm{~kW}$ as the fuel cell is assumed to be a $2 \mathrm{kWe}$ fuel cell. If there is need for up-regulating or down-regulating power, the unit is able to offer a downward regulation or upward regulation of $1 \mathrm{~kW}$. As the fuel cell runs at 50 percent of its capacity, the owner is able to achieve the stand by payment at any time as there is always the possibility to up or down regulate.

The analyses show that under the virtual power plant there is hardly any difference between the control strategies for a new house compared to an old house. The amount of electricity produced exceeds the electricity consumed by a factor five in the spot market case and a factor three in the regulating power market case. The fuel cell only covers between 17 and 55 percent of the heat consumption depending on scenario and housetype. In the spot market case the necessary price premium is $21.7 \mathrm{c} € / \mathrm{kWh}$ (Table 5) whereas in the regulating power market case the necessary price premium is $26.4 \mathrm{c} € / \mathrm{kWh}$.

Even though the fuel cell does not cover the total heat demand of the household, the fuel cell still operates in periods where there is no heating need in the house in combination with a full heating storage. In these situations we assume that the heat can be blown off costlessly. The fuel cell runs almost around the clock and despite the 
amount of blow-off, the fuel cell is not able to fulfil the heating demand of the household. The logic behind this is that the fuel cell in some periods produces even though there is no heating demand and the storage is full. In other periods, the heating demand exceeds the production of the fuel cell including the storage and the gas boiler runs in order to fulfil the heating demand. This effect would be altered if the heat storage was considerably larger.

Table 5 Virtual power plant - overview - Denmark

\begin{tabular}{|c|c|c|}
\hline & Spot market & Regulating power market \\
\hline Electricity production & $17451 \mathrm{kWh} /$ year & 10253 kWh/year \\
\hline Full load hours & $8725 \mathrm{~h}$ & $5127 \mathrm{~h}$ \\
\hline $\begin{array}{l}\text { Heat demand covered by FC } \\
\text { (Old/new) }\end{array}$ & 30/55 pct. & 17.4/32.4 pct. \\
\hline Price premium & $21.7 \mathrm{c} € / \mathrm{kWh}$ & $26.4 \mathrm{c} € / \mathrm{kWh}$ \\
\hline
\end{tabular}

\subsubsection{Summary}

The analyses for Denmark shows that net metering as support scheme is promising for households where the electricity consumption exceeds the electricity production of the fuel cell (i.e. the entire amount of electricity granted the support corresponding to the end consumer electricity price)

Furthermore, our analyses indicate that out of the two scenarios where the fuel cell is a part of a virtual power plant, the constellation where the fuel cell participates only on the day-ahead market is superior to the case with regulating power market participation.

\subsection{Country case: France}

\subsubsection{Thermal control}

For France we have analysed the thermal control scenario assuming one import tariff as well as the situation with two import tariffs: an off-peak and a peak tariff. In the thermal control strategy, the fuel cell runs during more full load hours in the old house compared to the new house in order to fulfil as much of the heat consumption as possible. Hence, the fuel cell in the old house produces more electricity compared to the fuel cell in the new house and the fuel cell is more profitable in the case of the old house. The results for the old house analyses are shown in Table 6.

The results from the two analyses (one import tariff and peak tariff) are very similar and shows that the necessary feed in tariff (with and without self-consumption) is approximately 36 and $28 \mathrm{c} € / \mathrm{kWh}$ respectively. The necessary feed-in tariff with selfconsumption is higher compared to the necessary feed in tariff without selfconsumption because the electricity price in France is lower than the necessary feedin tariff without self-consumption. For the hours where the fuel cell owner selfconsumes (in the case with self-consumption), the fuel cell owner "only" receives what corresponds to the end consumer price. Since the end consumer price is lower than the feed tariff without self-consumption, the owner has to be additionally compensated during the hours where he does not self-consume. 
Table 6 Thermal control - overview - France

\begin{tabular}{|c|c|c|}
\hline & One tariff & Peak tariff \\
\hline Electricity production & $5231 \mathrm{kWh} / \mathrm{year}$ & 5116 kWh/year \\
\hline Electricity export (net metering) & 2294 kWh/year & 2179 kWh/year \\
\hline Self-consumption & 1658 kWh/year & 1665 kWh/year \\
\hline $\begin{array}{lll}\text { Electricity } & \text { export } \\
\text { consumption) } & \end{array}$ & 3573 kWh/year & $3450 \mathrm{kWh} /$ year \\
\hline Full load hours & $5231 \mathrm{~h} /$ year & 5116 h/year \\
\hline Heat demand covered by FC & 34 pct. & 33 pct. \\
\hline Break even investment costs & $266 € / \mathrm{kW}$ & n.a. \\
\hline FIT & $28.2 \mathrm{c} € / \mathrm{kWh}$ & $28.7 \mathrm{c} € / \mathrm{kWh}$ \\
\hline FITS & $35.5 \mathrm{c} € / \mathrm{kWh}$ & $37.4 \mathrm{c} € / \mathrm{kWh}$ \\
\hline
\end{tabular}

As noted the results from the two analyses presented above do not differ significantly. In this section we will have a closer look into the differences and analyse why the differences are so small. We saw that the electricity production, electricity export and number of full load house are slightly higher in the case with one import tariff compared to the peak period case. The explanation is that under the peak period case, the control strategy assures that the fuel cell shift the running hours to the peak periods when possible. In this case the heat consumption in some periods exceeds the heat storage and therefore the gas boiler will cover the heat demand for a larger share overall resulting in lower production from the fuel cell.

On the other hand, as the amount of self-consumption is identical in the old house for both of the scenarios the share of the electricity produced being self-consumed in the peak period case exceeds the self-consumption in the case with one import tariff for the new house. So, a small amount of the operating hours has been shifted towards the peak periods. These are also the periods where the household has the largest electricity consumption.

The resulting feed-in tariffs mirror this, as the necessary feed-in tariffs in the peak period cases exceed the necessary feed in tariffs in the case with one import tariff in order to compensate for the lower electricity production (see Table 6).

The comparison reveals that introducing peak periods in the control strategy does not affect the strategy significantly and definitely not in a more profitable direction for the fuel cell. This can be seen as the feed-in tariffs taking the peak periods exceed the feed in tariffs not taking the peak periods into account.

\subsubsection{Virtual power plant - spot market}

Table 7, presents the results for the VPP based on the spot market for electricity. There is no difference between the technical simulation of the old house and the new house the except for the share of heat demand covered by the fuel cell. The table shows that there is reason for cautious optimism as the necessary price premium is $13.3 \mathrm{c} € / \mathrm{kWh}$.

The fuel cell runs around the clock and despite the amount of blow off the fuel cell is not able to fulfil the heating demand of the household. The logic behind this is that the 
fuel cell in some periods produces even though there is no heating demand and the storage is full and the heat is simply blown off costlessly. During other times of the day, the heating demand exceeds the production of the fuel cell plus the storage, and the gas boiler produces in order to fulfil the heating demand. This effect would be altered if larger heat storage was introduced.

Table 7 Virtual power plant - spot market - overview, France Old/new house

\begin{tabular}{ll}
\hline Electricity production & $17559 \mathrm{kWh} / \mathrm{year}$ \\
Full load hours & 8780 \\
Heat demand covered by FC (old/new) & $31 / 68 \mathrm{pct}$. \\
Price premium & $13.3 \mathrm{c€} / \mathrm{kWh}$ \\
\hline
\end{tabular}

\subsubsection{Summary}

The analyses for France demonstrates that for the consumer control scenarios, the most promising one is the standard thermal control feed-in tariff. The relatively low end consumer price in France reduces the attractiveness of feed in tariff with selfconsumption. As the end consumer electricity price is lower than the necessary feed in tariff (FIT) the necessary feed in tariff assuming self-consumption (FITS) has to be higher in order to compensate for the lower tariff indirectly received during selfconsumption.

The private economic analyses based on the VPP strategy showed reason for cautious optimism regarding this promotion scheme.

\subsection{Country case: Portugal}

\subsubsection{Thermal control}

For Portugal we have analysed the thermal control scenario assuming one import tariff as well as the situation with two import tariffs: an off-peak and a peak tariff. The results are marginally better for an old house compared to the new house and the results for the old house is presented in Table 8. The fuel cell runs less full load hours in a new house (4200) compared to the old house whereas the heat demand covered by the fuel cell is higher for the new house, i.e. 56 percent.

Table 8 Thermal control - overview - Portugal

\begin{tabular}{lll} 
& One tariff & Peak tariff \\
\hline $\begin{array}{l}\text { Electricity } \\
\text { production }\end{array}$ & $5231 \mathrm{kWh} /$ year & $5230 \mathrm{kWh} /$ year \\
$\begin{array}{l}\text { Electricity export } \\
\text { (self-consumption) }\end{array}$ & $3573 \mathrm{kWh} /$ year & $2293 \mathrm{kWh} /$ year \\
$\begin{array}{l}\text { Full load hours } \\
\text { Heat demand }\end{array}$ & $5231 \mathrm{~h} /$ year & 5230 \\
$\begin{array}{l}\text { covered by FC } \\
\text { FIT Self- }\end{array}$ & $34.6 \mathrm{c€} / \mathrm{kWh}$ & $34 \mathrm{pct}$. \\
$\begin{array}{l}\text { consumption n.a. } \\
\text { Necessary } \\
\text { investment support }\end{array}$ & n.a. & $9500 € / \mathrm{kW}$ \\
\hline
\end{tabular}


The necessary feed in tariff in the new house is also higher that for the old house (44.3 $\mathrm{c} € / \mathrm{kWh}$ ) pointing to the fact that as for the case with Denmark and France the fuel cell is more profitable to install in an old house compared to a new house as the number of full load hours is larger for an old house.

In the thermal control - peak period we assume that the fuel cell owner faces two end consumer electricity prices, i.e. peak and off peak. The support scheme found relevant to analyse is net metering. The profitability of the installation in the old house is marginally better compared to the new house, as the necessary investment support is $1200 € / \mathrm{kW}$ lower for the old house.

\subsubsection{Virtual power plant - spot market}

Table 9, presents the results for the VPP based on the spot market for electricity. There is no difference between the technical simulation of the old house and the new house the except for the share of heat demand covered by the fuel cell. The analyses show that the necessary price premium for Portugal is $13.9 \mathrm{c} € / \mathrm{kWh}$. The fuel cell runs round the clock 366 days a year. Due to its small dimensioning, the fuel cell only manages to cover 68 and 31 percent of the heat demand in a new and an old house respectively.

Table 9 Virtual power plant - spot market - overview Portugal
Old/new house

Despite the fact that the fuel cell does not cover the entire heat demand of the household, there are also periods where the fuel cell produces electricity and hence heat even though there is no heat demand nor storage room. In these situations the heat is assumed to be blown off costlessly.

\subsubsection{Summary}

The private economic analyses for Portugal showed that none of the consumer control scenarios are very promising. The relatively low end consumer electricity price in Portugal decreases the attractiveness of the feed in tariff with self-consumption as well as net metering

The private economic analyses based on the VPP strategy showed reason for cautious optimism regarding this promotion scheme.

\section{Sensitivity analysis}

We turn towards a number of sensitivity analyses changing the preconditions for important parameters:

- $\quad$ The fuel cell has a life time of 20 years instead of 10 . 
- $\quad$ O\&M costs are more than twice as high as in the base case scenario, i.e. 300 $€ / \mathrm{kW} /$ year.

- $\quad$ Stack lifetime of two years compared to the initially assumed five years.

- $\quad$ Stack lifetime of 10 years - i.e. that the stacks do not have to be replaced.

- $\quad$ Additional increase of one percent point in the electricity and gas price relative to the otherwise assumed inflation rate.

In general, the sensitivity analyses showed that increasing the lifetime of the fuel cell as well as the stacks improved the profitability of the fuel cells (e.g. decreased the necessary support). However, increasing the lifetime of the fuel cell or the stacks did not change substantially in the results under the given support scheme. Furthermore, at no time it changed the ranking of the support schemes.

Figure 2 Percentage change in the necessary price premium, VPP spot market

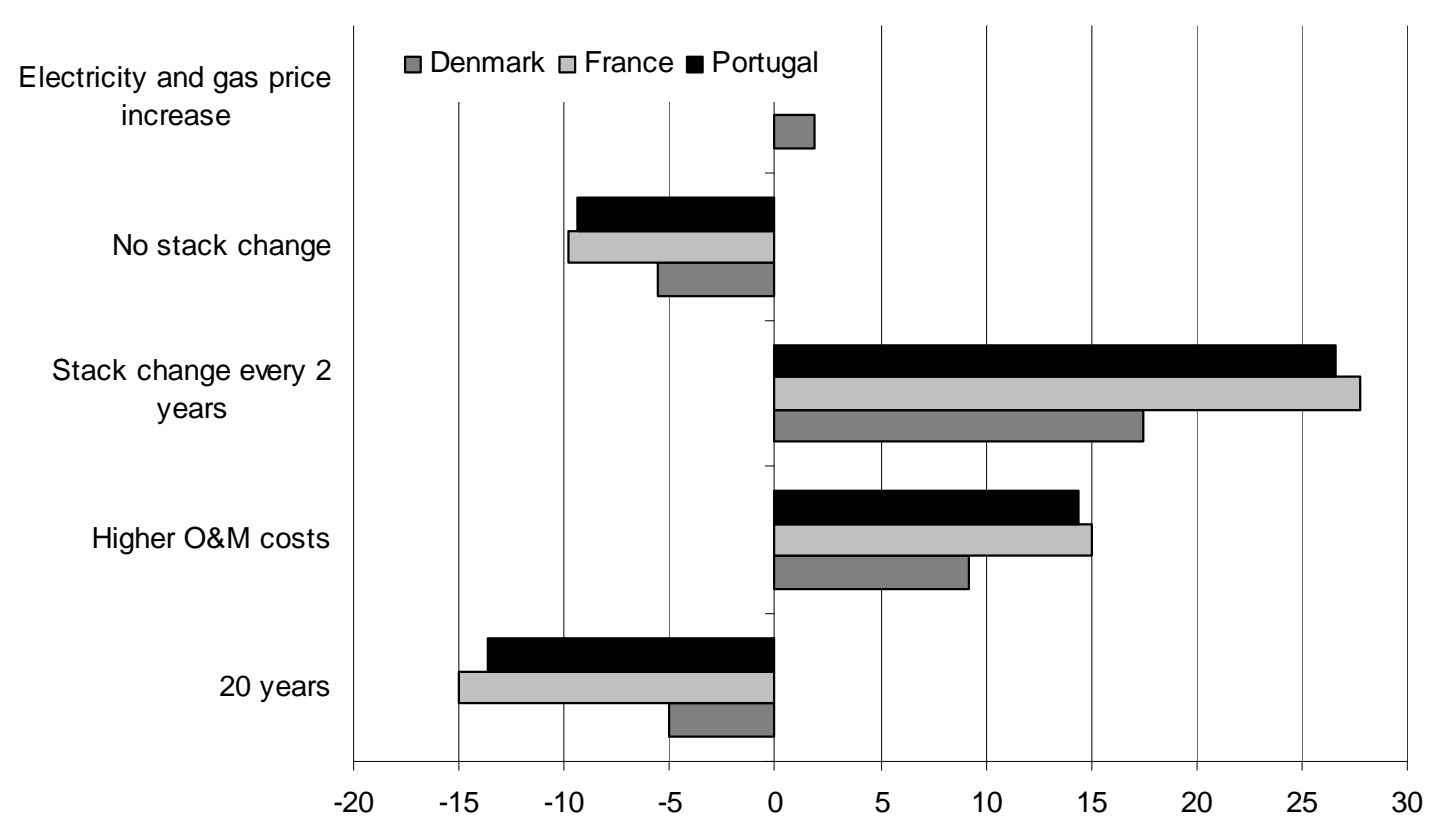

Changing the price development of electricity and gas relative to the general price level hardly changed the profitability. Assuming that the stacks had a lifetime of only two years rendered operation unprofitable under almost all of the support schemes. The effects on the necessary price premium assuming the fuel cell is operating as a part of a virtual power plant at the spot market is illustrated in Figure 2. For example, we see that the profitability of the fuel cell improved as the necessary price premium decreased (indicated as a negative value in the figure) as a result of a longer lifetime of the fuel cell or longer lifetime of the stacks. Shorter lifetime of the stack (two years) has the most severe effect on the necessary price premium.

\section{Discussion and conclusions}

In this article, we determine the necessary support level of residential fuel cells in order to assure profitability of the private investor. We take the point of departure in the technological stage of residential fuel cells, stakeholder opinions, technical 
simulations and a cash flow model and analyse in the light of combinations of ownership structure and support schemes which level of support the residential fuel cells should be provided with in Denmark, France and Portugal.

All calculations are based on 2008 numbers. This year has been chosen because it provides price levels and price variations that are average to high for Denmark and Portugal. Therefore, we regard it as a representative example for a possible future state. For France, the price level is clearly higher than in other years, so conditions are rather optimistic. In summary, 2008 is nevertheless the historical year that is most appropriate considering price levels and variabilities in the three focus countries.

We found that for Denmark, due to a rather high end consumer price, installing FC based micro CHP in households with a high electricity consumption, i.e. the electricity production from the FC does not exceed the electricity consumption in the household, would be promising assuming the support mechanism net metering.

In France and Portugal, the virtual power plant on the day ahead market appears to be the most promising support scheme - however, based on different background conditions. In France, the natural gas price is rather low giving the fuel cell running many hours an advantage. In Portugal the electricity spot price is relatively high improving the conditions for the electricity seller.

For France and Portugal, we find that the support mechanism based on self consumption in combination with feed in tariff has a poor performance. As the electricity price is lower than the necessary feed-in tariff without self-consumption, the owner has to be additionally compensated during the hours where he does not selfconsume and receive the feed in tariff self-consumption (FITS). The relatively low end consumer electricity price in France decreases the attractiveness of net metering compared to Denmark.

Overall we find that some technological development within FC-based micro CHP is necessary in order to make the technology truly interesting as the expected unit prices the next 5-10 years are too high. However, the necessary support levels found in the analyses are not excessive compared to the initial support levels for e.g. photovoltaic systems in Germany. Considering that the application of biogas in gas based FC's could contribute to achieving long-term low CO2 scenarios makes the found support levels promising.

The results we obtained for the virtual power plant scenarios shows that the fuel cell would be running almost permanently. Assuming that the lifetime is predominantly depending on operating hours, this decreases the lifetime of the fuel cell in years and worsens our results. On the other hand, it may provide an interesting option for units that are more prone to starts and stops instead of mere operating hours. However, our analyses are based on a rather conservative assumption regarding the investment costs, which to a certain extent is assumed to compensate for the abovementioned lifetime effect. In the virtual power plant scenarios, there is a considerable amount of blow off for all three countries. If the households had been provided with a larger heat storage, the amount of blow off would be reduced and the profitability could improve. Higher electrical efficiency and longer lifetimes would in general improve the results. The ability to modulate as well as the ability to cope with cold starts would especially improve the results for the thermal control scenarios. 
Stack replacement with better stacks gives a higher income to the risk-taking owner of the microCHP unit. This possibility is a real option and thus, constitutes an additional income stream that has been disregarded in the presented analyses.

Under existing legislation within the EU, only large-scale power plants and industrial facilities are subject to CO2 quota trading. Shifting a part of electricity generation from large-scale power plants to a decentral technology as microCHP fuel cells leads to additional $\mathrm{CO} 2$ from the non-quota households, while the $\mathrm{CO} 2$ being emitted from large-scale units stays constant. Therefore, the introduction of microCHP units could lead to additional $\mathrm{CO} 2$ emissions if existing policy schemes do not account for this change. The authors suggest that the $\mathrm{CO} 2$ cap must be reduced in line with expectations on the deployment of microCHP solutions.

The presented considerations and results are chiefly based on a partial analysis of support schemes. The authors would like to stress that an integrated view with other aspects can lead to sensible regulatory implementations. For example, some of our analyses show that less support is required for an older house with a higher heating demand, i.e. lower energy efficiency. This is undesirable for achieving a number of other political targets. In this case, it may be beneficial to set a slightly higher support level and combine it with incentives for energy efficiency measures. However, this should not lead to such a restricted customer circle that mass production and associated economies of scale are endangered. A careful weighting of different goals and policy instruments is necessary if microCHP fuel cells are to participate in the future energy supply.

\section{Acknowledgements}

The FC4Home project (Socio-Economic and Energy Systems Analysis of Micro Combined Heat and Power (Fuel Cell Technology), www.fc4home.com) is supported by the HY-CO ERA-NET scheme (Reference 001/2008) and funded by the Danish Energy Agency (Denmark), ADEME (France) and the Science and Technology Foundation (Portugal), for which we are grateful. The authors would like to thank Stephanie Ropenus for excellent collaboration and contributions in an earlier phase of the project. Furthermore, special thanks go to the colleagues from our institutions with whom we had fruitful discussions in the course of this project. The sole responsibility for the contents of this document lies with the authors and does not represent the opinions of the funding organisations.

\section{References}

[1] W. Krewitt, J. Nitsch, M. Fischedick, M. Pehnt, H. Temming, Market perspectives of stationary fuel cells in a sustainable energy supply system long-term scenarios for Germany, Energy Policy 34 (2006) 793-803.

[2] C. R. Karger and R. Bongartz, External determinants for the adoptatioon of staionary fuel cells - Intrastructure and policy issues, Energy Policy 36 (2008) 798810. 
[3] S.T. Schroeder, A. Costa, E. Obé, Support schemes and ownership structures - the policy context for fuel cell based micro-combined heat and power, J. Power Sources 196 (2011) 9051-9057.

[4] A.D. Hawkes, M.A. Leach, Cost-effective operating strategy for residential microcombined heat and power, Energy 32 (2007) 711-723.

[5] K. Nanaeda, F. Mueller, J. Brouwer, S. Samuelsen, Dynamic modeling and evaluation of solid oxide fuel cell - combined heat and power system operating strategies, J. Power Sources 195 (2010) 3176-3185.

[6] Y. Hamada, R. Goto, M. Nakamura, H. Kubota, K. Ochifuji, Operating results and simulations on a fuel cell for residential energy systems, Energy Conv Man 47 (2006) 3562-3571.

[7] B.V. Mathiesen, P.A. Østergaard, Solid oxide fuel cells and large-scale integration of intermittent renewable energy, in: B.V. Mathiesen, Fuel cells and electrolysers in future energy systems, $\mathrm{PhD}$ thesis, Department of Development and Planning, Aalborg University, 2008, 29-45.

[8] I. Staffell, R. Green, K. Kendall, Cost targets for domestic fuel cell CHP, J. Power Sources 181 (2008) 339-349.

[9] W. Colella, Design options for achieving a rapidly variable heat-to-power ratio in a combined heat and power (CHP) fuel cell system (FCS), J. Power Sources 106 (2002) 388-396.

[10] B.V. Mathiesen, H. Lund, F. Hvelplund, P.A. Østergaard, Comparative energy system analysis of individual house heating in future renewable energy systems, in: B.V. Mathiesen, Fuel cells and electrolysers in future energy systems, $\mathrm{PhD}$ thesis, Department of Development and Planning, Aalborg University, 2008, 93-113.

[11] I. Staffell, R.J. Green, Estimating future prices for stationary fuel cells with empirically derived experience curves, Int. J. Hydrogen Energy 34 (2009) 5617-5628.

[12] R. Rivera-Tinoco, K. Schoots, B. van der Zwaan, Learning curves for solid oxide fuel cells, Energy Conv and Man 57 (2012) 86-96

[13] A.D. Hawkes, M.A. Leach, On policy instruments for support of micro combined heat and power, Energy Policy 36 (2008) 2973- 2982.

[14] T. Wakui, N. Wada, R. Yokoyama, Feasibility study on combined use of residential SOFC cogeneration system and plug-in hybrid electric vehicle from energy-saving viewpoint, Energy Conv Man 60 (2012) 170-179.

[15] M. De Paepe, P. D’Herdt, D. Mertens, Micro-CHP systems for residential applications, Energy Conv Man 47 (2006) 3435-3446.

[16] M. De Paepe, D. Mertens, Combined heat and power in a liberalised energy market, Energy Conv Man 48 (2007) 2542-2555.

[17] K. Alanne, N. Söderholm, K. Sirén, I. Beausoleil-Morrison, Techno-economic assessment and optimization of Stirling engine micro-cogeneration systems in residential buildings, Energy Conv Man 51 (2010) 2635-2646.

[18] V. Dorer, A. Weber, Energy and CO2 emissions performance assessment of residential micro-cogeneration systems with dynamic whole-building simulation programs, Energy Conv Man 50 (2009) 648-657

[19] J. Cockroft, N. Kelly, A comparative assessment of future heat and power sources for the UK domestic sector, Energy Conv Man 47 (2006) 2349-2360 
[20] A. Hawkes, M. Leach Solid oxide fuel cell systems for residential microcombined heat and power in the UK: Key economic drivers. J. Power Sources 149 (2005) 72-83.

[21] L. Pade, S.T. Schröder, M. Münster, P.E. Morthorst, Analyses of models for promotion schemes and ownership arrangements. FC4home project report, 2011. Available www.man.dtu.dk/upload/institutter/man/publikationer\%202012/rap8.2012final.pdf

[22] A. Huber, Residential fuel cell micro CHP in Denmark, France and Portugal: Analyzing actor perceptions. FC4home project report, 2010. Available (18.01.2012): www.fc4home.com

[23] R. Sauter, J. Watson, Strategies for the deployment of micro-generation: Implications for social acceptance, Energy Policy 35 (2007), 2770-2779.

[24] J. Barquín, L. Rouco, E. Rivero, Current designs and expected evolutions of Day-ahead, Intra-day and balancing market/ mechanisms in Europe. OPTIMATE project report, May 2011. Available (24.10.2012): http://www.optimateplatform.eu/workplan/download/d22-d331-d332-d32-current-designs-and-expected-

evolutions-of-day-ahead-intra-day-and-balancing-market-mechanisms-ineurope.49.html

[25] E. Obé, E. Kötter, Residential fuel cell micro CHP in Denmark, France and Portugal: Results simulation analysis. FC4home project, 2011, Work Package 5 Report (www.fc4home.com)

[26] W. Iwasaki, Residential fuel cell (ENE-FARM) and carbon neutral supply system (CNES), Energy Transitions - A joint seminar series between Tokai University and Technical University of Denmark (DTU). Tokai/Roskilde, 17.10.2012. [27] Fuel Cell Bulletin. CFCL BlueGen units for virtual power plant project in Netherlands. July 2012.

[28] Topsoe technical data on "PowerCore“ system, Available (24.10.2012): http://www.topsoefuelcell.com/products/powercore/next_generation.aspx

[29] Topsoe Fuel Cell, Outlook \& Business August 2010. Available (24.10.2012): http://www.risoe.dtu.dk/en/Research/sustainable_energy/fuel_cells/projects/SERC/M eetings/ /media/Risoe_dk/Research/SERC/Documents/100826_Summer\%20School\% 20-\%20Inger\%20Byriel/100826_TOFC\%20Outlook\%20and\%20business_HHL.ashx [30] IRD, Household CHP System. Available (19.01.2012): http://www.ird.dk/pdf/IRDpemicroCHP.pdf

[31] US Department of Energy, Future Fuel Cells R\&D, Available (24.10.2012): http://www.fossil.energy.gov/programs/powersystems/fuelcells/

[32] A. Kazim, Exergoeconomic analysis of a PEM fuel cell at various operating conditions. Energy Conv Man 2005 (46) 1073-1081.

[33] ENE FARM, Fuel Cell Systems for Residential Use, Available (24.10.2012): http://www.igu.org/knowledge/publications/mag/oct-

09/igu_october_2009_7_pages_186-217.pdf

[34] Panasonic, Technical data on "ENE FARM", Available (16.06.2011): http://panasonic.net/ha/e/FC/doc03_00.html

[35] S. Curtin, Clean, Green and Efficient: Fuel Cells Head Home, 2010. Available (19.01.2012): http://www.fuelcells.org/info/residentialarticle.pdf 
[36] Korea Economic Institute, Hydrogen and Fuel Cell Activities in Korea (2008). Available (15.06.2011): http://www.keia.org/Publications/Other/LeeFINAL.pdf

[37] UTC website: http://www.utcpower.com/

[38] H. Wendt, Stationary Fuel Cells (Stationäre Brennstoffzellen), 2006. Available (24.10.2012):

http://www.vdi.de/fileadmin/vdi_de/redakteur_dateien/get_dateien/Brennstoffzellen/S tationaere-BZ-Wendt-BWK_10-06.pdf

[39] Berkeley National Laboratory: Current trends of decentralized CHP integration, 2007. Available (24.10.2012):

http://eetd.lbl.gov/ea/ems/reports/62314.pdf

[40] G. Erdmann, Market introduction cost aspects of stationary fuel cells (Kostenfragen bei der Markteinführung von stationären Brennstoffzellen). Available (24.10.2012):

http://www.tuberlin.de/fileadmin/f12/Downloads/koop/publikationen/09_02_br4_erdmann.pdf

[41] DONG Energy. Typical household electricity consumption. Available (24.10.2012):

www.dongenergy.dk/privat/energiforum/tjekditforbrug/typiskelforbrug/Pages/hus.asp $\underline{\mathrm{x}}$

[42] Danish Renewable Energy Support Act (Lov om fremme af vedvarende energi). Available

(24.10.2012):

www.retsinformation.dk/Forms/R0710.aspx?id=122961 